\title{
The Effects of NAFTA on Antidumping and Countervailing Duty Activity
}

\author{
Bruce A. Blonigen
}

\begin{abstract}
Treatment of unfair trade laws has become an important topic in negotiations on preferential trading areas. Recent preferential trading areas involving the United States, one of the most significant users of these laws, have established special binational dispute settlement panels to arbitrate disagreements. Using a panel database of U.S. antidumping and countervailing duty activity from 1980 through 2000, the article examines whether the use of dispute settlement panels has reduced such activity between the United States and its North American Free Trade Agreement partners. The analysis finds little evidence for any effect, calling into question the effectiveness of dispute settlement panels in reducing unfair trade law activity.
\end{abstract}

With the success of multilateral trade negotiation rounds under the General Agreement on Tariffs and Trade (GATT) and the World Trade Organization (WTO) in reducing traditional forms of trade protection, such as tariffs and quotas, attention has turned to the use of antidumping and countervailing duty laws by WTO member countries. In some countries, these laws have been on the books since well before the GATT/WTO existed. However, as GATT/WTO membership has grown over the past two decades, such activity has exploded. ${ }^{1}$

This trend is worrisome for its implications for the ultimate effectiveness of recent and future GATT/WTO rounds. It may be that countries with antidumping and countervailing duty laws are willing to negotiate greater reductions in other forms of trade protection, since such laws allow the most import-sensitive sectors a channel of relief when negotiated reductions in trade barriers take place. But it is also the case that increased antidumping and countervailing duty activity may seriously undermine free trade agreements that do not fully address

Bruce A. Blonigen is a professor in the Department of Economics at the University of Oregon, Eugene, and a research associate at the National Bureau of Economic Research. The author thanks Daniel Lederman, Jaime de Melo, and anonymous referees for excellent comments on previous drafts.

1. See Prusa (2001) for analysis of the recent spread of antidumping and countervailing duty laws and their use across WTO member countries. Blonigen and Prusa (2003) provide an extensive survey of the literature on the economics of antidumping activity.

THE WORLD BANK ECONOMIC REVIEW, VOL. 19, NO. 3, pp. 407-424

doi:10.1093/wber/lhi014

Advance Access publication December 6, 2005

(C) The Author 2005. Published by Oxford University Press on behalf of the International Bank for Reconstruction and Development / THE WORLD BANK. All rights reserved. For permissions, please e-mail: journals.permissions@oxfordjournals.org. 
the use of such laws. ${ }^{2}$ In recent wTO meetings, it has become apparent that traditional users of antidumping and countervailing duty laws, particularly the United States, have been extremely reluctant to allow such laws even to be put on the agenda of future WTO negotiations. As the Doha Round has stagnated, countries have focused efforts on negotiating preferential trading areas.

The United States is a substantial user of antidumping and countervailing duty laws and also has made renewed efforts in the past decade to negotiate preferential trading areas. In both the Canadian-U.S. Free Trade Agreement (CUSFTA) and the North American Free Trade Agreement (NAFTA), the United States strongly resisted calls by Canada and Mexico for suspension of antidumping and countervailing duty activity. ${ }^{3}$ Instead, a compromise was reached, and codified in Chapter 19 of CUSFTA and NAFTA, to establish binational panels to review antidumping and countervailing duty actions between member countries when requested by an involved party (Gantz 1998). ${ }^{4}$ Did this compromise solution have any impact on antidumping and countervailing duty activity? The answer is important not only for future preferential trading areas negotiated by the United States, such as the Free Trade Area of the Americas, ${ }^{5}$ but also for any bilateral or multilateral trade negotiations involving countries with such laws.

On the one hand, the NAFTA binational dispute panels might not be expected to have much effect, since they are limited to determining whether a country appropriately followed its own national laws in making a particular antidumping or countervailing duty determination. Thus, the review panels can neither question nor change such laws, which was a crucial issue for the United States. On the other hand, the process provides an alternative to having national courts handle appeals of antidumping and countervailing duty decisions, thus offering the possibility of greater impartiality. ${ }^{6}$ And, in fact, virtually all appeals of U.S. antidumping and countervailing duty decisions by Canada and Mexico since NAFTA have came through the dispute settlement mechanism rather than national courts of appeals, and the dispute panels have often remanded decisions to U.S. agencies, resulting in changes to the original rulings (Macrory 2002). In addition, Jones (2000) finds that both U.S. antidumping filings against Canada

2. While antidumping and countervailing duty activity often involves narrowly specified import products, the high duties often imposed and other features of the administration of these programs can result in substantial welfare impacts. Gallaway, Blonigen, and Flynn (1999), using 1993 data, estimate that U.S. antidumping and countervailing duty programs cost the United States $\$ 4$ billion annually.

3. In January 1994, CUSFTA was incorporated into NAFTA, which was expanded to include Mexico.

4. The Chapter 19 review process was separate from a more general dispute settlement mechanism for all NAFTA-related issues stipulated in Chapter 20.

5. The U.S. use of antidumping and countervailing duty laws has been a particular concern to Argentina and Brazil in the negotiations for a Free Trade Area of the Americas (FTAA). For example, a January 31, 2001, front-page article in Brazil's Gazeta Mercantil reported that antidumping issues had led to an FTAA negotiation impasse between Brazil and the United States.

6. The national courts of appeals for unfair trade cases are the Court of International Trade of the United States, the Federal Court of Canada, and the Federal Fiscal Tribunal of Mexico. 
and Canada's antidumping filings against the United States dropped significantly after CUSFTA, which he attributes to the dispute settlement process. ${ }^{7}$

This article provides a more detailed empirical examination of U.S. antidumping and countervailing duty actions from 1980 through 2000 to determine the effects, if any, of the dispute settlement panels established under CUSFTA and NAFTA on U.S. antidumping and countervailing duty activity with respect to Canada and Mexico. ${ }^{8}$ This article improves on Jones's (2000) statistical approach in a number of ways. First, Jones limits his sample to observations on U.S. and Canadian antidumping and countervailing duty activity. This holds each regression to just 18 observations and does not adequately control for trends in U.S. antidumping and countervailing duty activity that may affect all countries equally. In contrast, this article samples and estimates U.S. antidumping and countervailing duty activity across all U.S. import sources, a better strategy for distinguishing the effects of Chapter 19 on U.S. antidumping and countervailing duty activity against its NAFTA partners from other general trends in such U.S. activity. Second, Jones estimates the effects of the Chapter 19 dispute settlement process through a simple dummy variable indicating the years since CUSFTA was established. Such a variable could be picking up the effects of myriad other changes that may have coincidently occurred after the establishment of the dispute settlement process. This article uses detailed measures of actual Chapter 19 dispute settlement activity to more accurately test the effect on antidumping and countervailing duty activity. Finally, Jones examines only the impact on the frequency of U.S. antidumping and countervailing duty cases against Canada, not on the outcomes. The analysis here examines the impact not only on U.S. filings but also on the likelihood of successful filings.

In contrast to the previous literature, this analysis finds little evidence that Chapter 19 has significantly affected U.S. antidumping and countervailing duty activity against its NAFTA partners. In particular, for Mexico there is no evidence that Chapter 19 activity significantly lowered U.S. filings or the number of affirmative decisions. This result is robust to measuring Chapter 19 activity as recent filings or as recent filings that led to remands for U.S. government agencies to redetermine their original decisions. The results are also statistically insignificant when Chapter 19 activity is specified as cumulative filings or remands rather than as those from the previous year. There is likewise no evidence that Chapter 19 dispute settlement filings or remands affected the

7. A few law journal articles and U.S. General Accounting Office (now the Government Accountability Office) reports have observed a number of developments in the operation of the binational review panels stipulated under Chapter 19. U.S. GAO (1997); Vega-Canovas (1997); Gantz (1998); and Pippin (1999) assess how well the binational panel system reviews have worked in fulfilling their stipulated goals.

8. The primary focus on U.S. antidumping and countervailing duty activity is due to data accessibility issues, as well as the fact that the United States is the largest market in NAFTA and the largest user of antidumping and countervailing duty laws. 
number of U.S. cases against Canada. This contrasts with the findings of Jones (2000). However, there is evidence that cumulative Chapter 19 filings and remands did lower the number of affirmative U.S. antidumping and countervailing duty decisions for Canada. Surprisingly, import penetration is not found to be a statistically significant variable for determining U.S. antidumping and countervailing duty activity, so the increased trade volumes resulting from CUSFTA and NAFTA also are unlikely to have affected U.S. activity.

\section{Antidumping and Countervailing Duty Investigations and Chapter 19 Dispute Settlement Procedures}

There are many common features in the application of antidumping and countervailing duty protection across countries, primarily because successive rounds of GATT/WTO multilateral trade negotiations have codified standard practices. ${ }^{9}$

Antidumping and countervailing duty cases begin with a petition from a domestic industry (or related party such as a labor union or trade association) for protection against imports that are allegedly being dumped-sold at unfairly low prices. Before remedies can be put into place, the appropriate authorities must rule on whether the alleged unfair trade practice is occurring and if so on whether it has caused or threatened to cause "material injury" to the domestic industry. For antidumping cases, the authorities first determine whether dumping is actually occurring by comparing transactions in the import market against some measure of "fair" or "normal" value. For countervailing duty cases, the authorities must determine whether the foreign government is providing an export subsidy to its firms and then calculate the magnitude of such subsidy. Then, for both antidumping and countervailing duty cases, the authorities must examine economic data such as import penetration, domestic industry performance, and macroeconomic effects and decide whether the imports are a significant cause of injury or potential cause of injury.

If material injury is found, the authorities impose duties to remedy the "unfair" imports. U.S. statutes allow for appeals of antidumping and countervailing duty decisions through a number of channels. Parties can appeal decisions to a higher national court within the country applying the unfair trade remedy. As WTO members, involved parties and governments can also take decisions to the WTO dispute settlement process.

CUSFTA and NAFTA added another avenue for appeal, Chapter 19, which permits bypassing national courts and appealing decisions directly to a fivemember binational review panel. Two panel members must come from each

9. The NAFTA negotiations also pushed Mexico to reform its antidumping and countervailing duty laws in a number of substantial ways. Most of the reforms were to add the much-needed due process features to Mexican procedures, including the abolition of provisional duties before preliminary decisions, full participation by involved parties in the administrative process, timely written notifications of decisions, and the right to immediate appeals. See Giesze (1994) and Pippin (1999) for further details. 
country represented in the dispute, drawn from a list of 25 people designated by each country. The fifth member is chosen from the list of one of the represented countries. In practice, countries seem to take turns choosing this fifth member.

The panel is charged with establishing whether the national authority made errors in "fact or law" in its determination, as set out in the complaint. Thus, the application of the national antidumping or countervailing duty law is under review, not the laws themselves. The panel either affirms the original decision or remands the decision to the national authority for reconsideration. Panels cannot reverse or dismiss a decision. Application of unfair trade remedies is not affected unless a dispute settlement panel remands a decision to the national authority and the authority changes its original ruling.

The consensus seems to be that the panels were working well under CUSFTA (before NAFTA), with judgments that were considered fair, noncontroversial, and impartial for both countries (see, for example, U.S. GAO 1997, p. 14). Many of the early decisions under CUSFTA were being administered within the stipulated 315 days, a substantial improvement over the standard timeline of national appeals courts. However, implementation under NAFTA has gone less smoothly. In particular, cases concerning Mexico have not been timely, causing concern on the part of Mexican officials. Part of the problem has been language difficulties and finding qualified Mexican experts to sit on the panels. In addition, satisfaction with panel decisions involving both Canada and Mexico has been much lower with the higher profile cases, such as the pork, swine, and softwood lumber cases. The lumber case was ultimately resolved by high-level negotiations between the United States and Canada, not through the Chapter 19 settlement process.

\section{Hypotheses}

CUSFTA and NAFTA led to two developments that could substantially affect U.S. antidumping and countervailing duty activity-increased imports and a new dispute resolution mechanism. To the extent that import penetration increases antidumping and countervailing duty activity, the increase in imports from Canada and Mexico could lead to an increase in U.S. antidumping and countervailing duty filings against NAFTA partner countries. Thus, import penetration (the value of a country's imports as a share of U.S. GDP) would be expected to be positively correlated with U.S. antidumping and countervailing duty activity.

The new dispute settlement mechanism under CUSFTA and NAFTA brought greater external scrutiny of U.S. administration of its antidumping and countervailing duty laws, which might reduce the incidence of such activity with respect to Canada and Mexico. There were 48 filings by Canada and 20 filings by Mexico against the United States through 2000 (table 1). For both countries in roughly a third of the cases, the original decision by the U.S. agencies was affirmed, in a third the cases were remanded to the U.S. authorities for reconsideration, and in a third the cases were terminated (withdrawn) before the panel made any decision. As discussed by Jones (2000), in a handful of cases the 


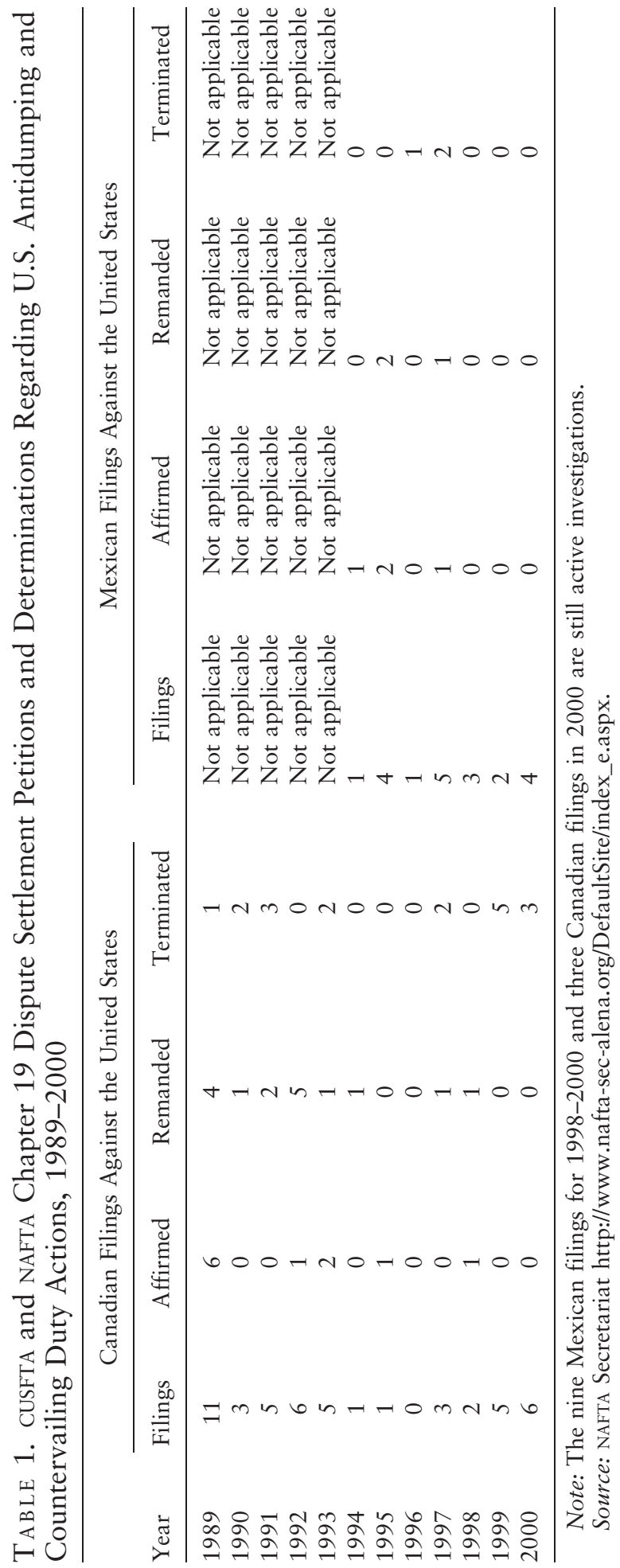


Figure 1. Three-Year Moving Average of Canadian and Mexican Share of Total U.S. Antidumping and Countervailing Duty Activity, 1980-2000

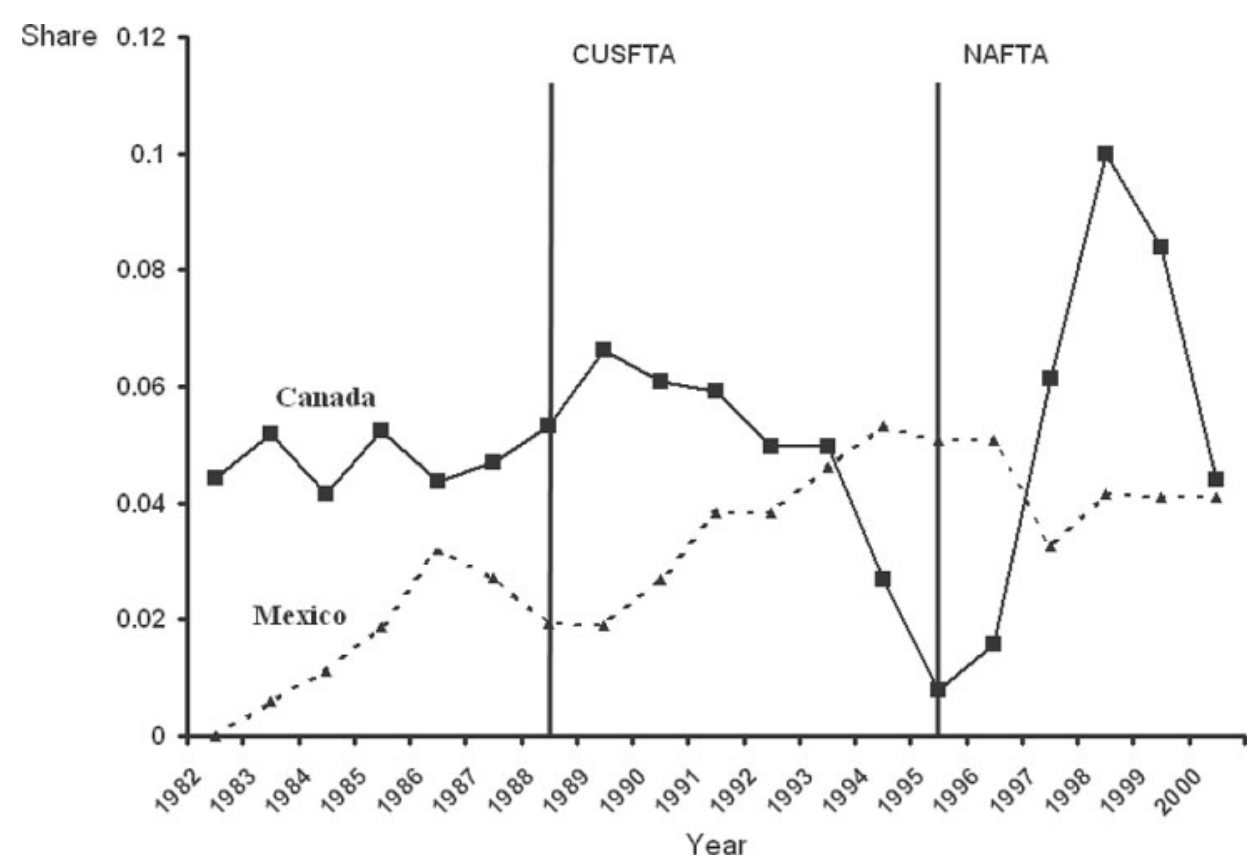

Source: Author's analysis using data on U.S. antidumping and countervailing duty cases reported in the Federal Register. Some of the data are available from the author's U.S. antidumping web page: http://darkwing.uoregon.edu/ bruceb/adpage.html.

remands led to some changes from the original decision. ${ }^{10}$ While there was significant activity involving both countries, Mexican cases have generally taken longer, with cases filed in 1998 (or later) still to be determined as of this writing. This may lead to some differences in the effect of Chapter 19 activity on U.S. antidumping and countervailing duty cases.

There is little evidence based on the number of cases of a significant change in the average share of U.S. antidumping and countervailing duty activity for Canada after CUSFTA or for Mexico after NAFTA (figure 1). While this simple analysis suggests little effect of Chapter 19 activity on U.S. antidumping and countervailing duty actions against its NAFTA partners, other factors that may not be particular to the NAFTA partners may have been affecting U.S. antidumping and countervailing duty activity during these time periods. Econometric analysis is needed to control for these other factors.

10. These are documented in Jones (2000, table 2). The largest change was a remand that led to elimination of the countervailing duty on Canadian softwood lumber, which then led to negotiations between the United States and Canada. U.S. cases against red raspberries, pork, steel rail, live swine, and magnesium also had remands that resulted in somewhat lower duties. 


\section{ECONOMETRIC Analysis}

An empirical model was developed to estimate the impact of NAFTA on antidumping and countervailing duty activity. The dependent variable is the number of U.S. antidumping and countervailing duty petitions against a particular import source for a given year. ${ }^{11}$ Following standard practice, petitions across import sources and time are assumed to follow a discrete distribution-the negative binomial distribution. It can be assumed that the parameter governing the frequency of antidumping and countervailing duty actions for these distributions is a linear function of explanatory variables. The effect of these explanatory variables on the observed frequency of antidumping and countervailing duty actions can then be estimated through maximum likelihood techniques. ${ }^{12}$

The list of included explanatory variables begins with import penetration. As discussed in the Hypotheses section, increased import penetration is expected to have a positive impact on U.S. antidumping and countervailing duty activity against the source country. Thus, the coefficient on import penetration can provide an estimate of the effect of increased import penetration by NAFTA partners on U.S. antidumping and countervailing duty activity toward these partners.

A number of annual Chapter 19 filings by Canada and Mexico are used to test the effect of Chapter 19 activity on U.S. antidumping and countervailing duty activity against its NAFTA partners. Since Canadian filings are expected to affect U.S. activity only against Canada and analogously for Mexico, each filing measure is interacted with a dummy variable indicating the import source. The expectation is that a greater number of Chapter 19 filings will reduce current filings and affirmative decisions of U.S. antidumping and countervailing duty cases against Canada and Mexico. Because U.S. filings and decisions may be affected only when Chapter 19 filings led to reconsiderations of previous cases, an alternative estimate considers measures of annual Chapter 19 remands as an explanatory variable as well. The analysis assumes that there were no other changes (legal or otherwise) that altered incentives for parties to pursue other channels of appeal.

In determining appropriate explanatory variables, the analysis here follows a number of previous statistical analyses of the factors that determine the

11. An alternative measure of activity is the volume of imports subject to investigations from a particular import source in a given year, since a count measure makes the implicit assumption that all cases are equally important in terms of import volume. However, import volumes for products subject to antidumping and countervailing duty investigations are often not publicly reported because of confidentiality concerns when the case involves a small number of firms.

12. Examples of such papers using maximum likelihood estimation of Poisson or negative binomial distributions to model the frequency of U.S. antidumping activity include Feinberg (1989); Feinberg and Hirsch (1989); Jones (2000); and Knetter and Prusa (2003). A more extensive literature has examined the factors that determine the outcomes of these filed petitions, including Finger, Hall, and Nelson (1982); Moore (1992); DeVault (1993); Baldwin and Steagall (1994); Blonigen and Feenstra (1997); and Hansen and Prusa (1997). 
frequency of U.S. antidumping and countervailing duty action generally. Following Knetter and Prusa (2003), real U.S. GDP growth and the real exchange rate (foreign currency per U.S. dollar, specific to each country or region) are included, with lower real GDP growth and appreciation of the U.S. currency relative to the import sources expected to make antidumping and countervailing duty filings more likely. Following Jones (2000), corporate profitability and unemployment variables are included, with lower corporate profitability and higher unemployment expected to increase U.S. filings. Change in import penetration is included to control for any effect of import penetration not explained by exchange rate movements, such as trade protection changes instituted by CUSFTA and NAFTA. Higher import penetration is expected to be associated with greater filing activity. Following Knetter and Prusa (2003), the explanatory variables are lagged by one year, since U.S. authorities use economic data from recent previous years to determine dumping and injury. Regional fixed effects are also included to control for unobserved region-specific features that may increase or decrease the incidence of U.S. antidumping and countervailing duty activity against a particular region, everything else being equal.

\section{Data}

To serve as controls, data on U.S. antidumping and countervailing duty activity with respect to other import sources are also included. Thus, the dataset consists of a balanced panel covering 1980 through 2000 and includes seven import sources: Canada, Mexico, Japan, the European Union, Latin America excluding Mexico, Asia excluding Japan, and the rest of the world. The first four countries and regions are the major U.S. trading partners, and the final three are commonly used regional groupings. Starting the sample in 1980 is standard in the literature, as this is the year when the United States made a major change in its antidumping and countervailing duty laws and activity. With seven regions and 21 years, the sample numbers 147 observations. ${ }^{13}$

Data on U.S. antidumping and countervailing duty filing activities and decisions for 1980-2000 for the dependent variable come from the U.S. Antidumping Database constructed by the author and available from the National Bureau of Economic Research web site (http://www.nber.org/antidump). Data on Chapter 19 dispute settlement proceedings and decisions are available from the NAFTA Secretariat (http://www.nafta-sec-alena.org/DefaultSite/index_e.aspx). Data on annual U.S. corporate profits, U.S. unemployment rate, and U.S. GDP growth rate are from Economic Report of the President (Council of Economic Advisers 2002, tables B-94, B-42, and B-1). Data on import flows come from the Direction of Trade Statistics Yearbook (IMF various years).

13. In contrast, Jones (2000) runs separate equations for the United States and Canada covering 1980-97, which means that each regression is based on only 18 observations and does not benchmark relative to a control group. 
Real exchange rate data for Mexico, Canada, and Japan come from the Economic Research Service of U.S. Department of Agriculture (USDA ERS) and are available from its web site (http://www.ers.usda.gov/data/sdp/). The real exchange rate for the rest of the world comes from the broad index of the real U.S. dollar exchange rate of the Economic Report of the President (Council of Economic Advisers 2002, table B-110). And the real exchange rate for the European Union, Latin American, and Asian regions are calculated as tradeweighted averages of the real exchange rates for important countries from those regions, using the USDA ERS dataset. Each real exchange rate index was normalized by dividing each annual observation by the index's sample mean.

Table 2 provides descriptive statistics for the explanatory variables and dependent variables used in the statistical analysis, as well as the expected sign on the coefficient for each explanatory variable.

\section{Econometric Analysis: Initial Specifications}

The results of the negative binomial maximum likelihood estimates of the explanatory factors for U.S. antidumping and countervailing duty filings and affirmative decisions are reported for the total annual number of U.S. filings and for affirmative decisions only (table 3). Many of the general results also hold for alternative estimates, as discussed below.

The overall fit of the equation is generally good, with a Wald statistical test easily rejecting the hypothesis of jointly insignificant explanatory variables at the 99 percent confidence level. While the fit of the equation is statistically significant, the control variables are generally not, though four of the five have the expected sign. The general pattern for the alternative estimations is for import penetration, the exchange rate, and corporate profitability to have the expected sign, with coefficients for corporate profitability and the exchange rate often statistically significant at standard confidence levels. The result that exchange rate appreciation is correlated with higher U.S. antidumping and countervailing duty activity accords with the findings of Knetter and Prusa (2003). Jones (2000) finds that lower U.S. corporate profitability led to a greater incidence of U.S. antidumping and countervailing duty activity.

Several of the regional fixed effects are statistically significant and yield an interesting pattern. In particular, both Canada and Mexico have statistically significant negative coefficients, with the estimates suggesting that both countries experience about six fewer U.S. duty cases each year than the omitted regional fixed effect, rest of the world, everything else being equal. ${ }^{14}$

With respect to the focus variables, there is little evidence that NAFTA Chapter 19 filings affect annual U.S. antidumping and countervailing duty filings. The coefficient on NAFTA dispute settlement filings by Canada is, as expected,

14. Marginal effects are not the coefficient estimates in this nonlinear specification. Rather, they were numerically calculated using the econometric package STATA. 


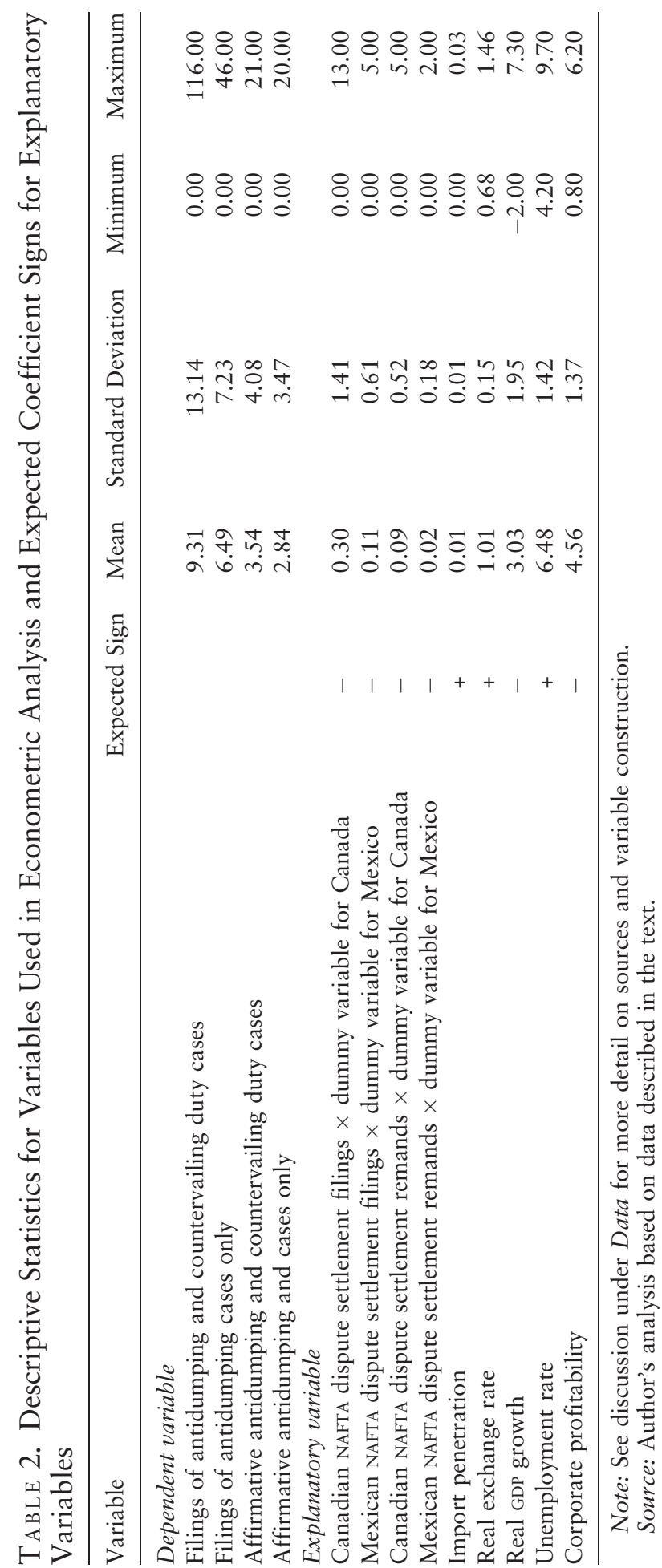




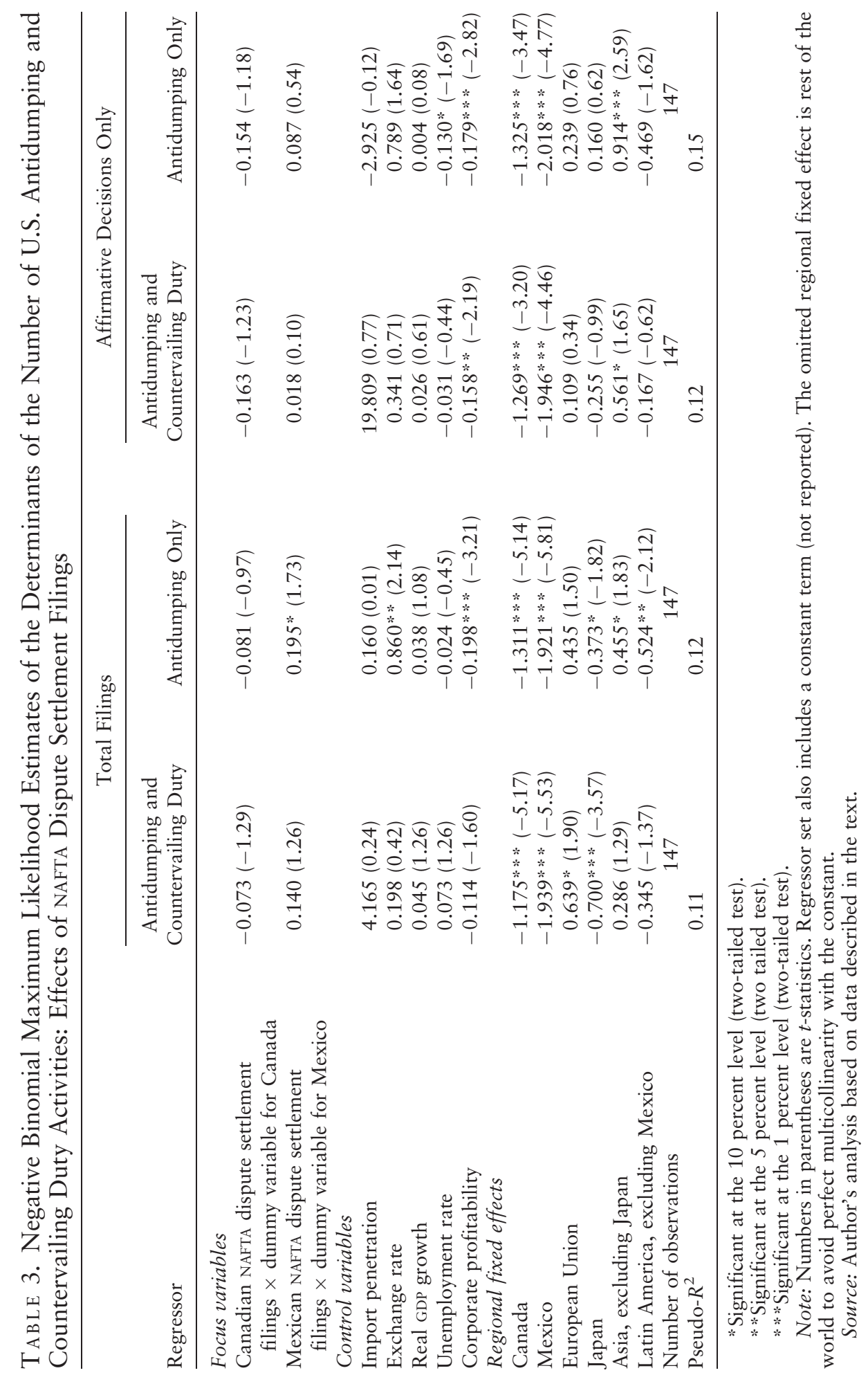


negative (suggesting that greater Canadian dispute filings decrease U.S. antidumping and countervailing duty filings against Canada), but is not statistically significant at standard confidence levels. The coefficient on NAFTA dispute settlement filings by Mexico is positive, opposite to the hypothesized sign, and statistically insignificant as well. Although import penetration increased after NAFTA for both Canada and Mexico, the coefficient on import penetration is statistically insignificant, meaning that import penetration had no discernible impact on U.S. antidumping and countervailing duty filings related to NAFTA.

Because antidumping activity might respond differently to NAFTA effects than countervailing duty activity, the regression was also estimated with the number of U.S. antidumping filings only as the dependent variable (table 3, column 2). This alternate specification has little impact on any of the coefficients, although the fit of the equation is somewhat better and more variables display statistical significance.

While NAFTA dispute settlement filings might not deter domestic firms in the United States from filing antidumping and countervailing duty cases, the filings might make U.S. government authorities less likely to rule affirmatively in antidumping and countervailing duty cases. After all, it is their decisions, and hence their credibility, that is under review by the dispute settlement panels. When the regressions are estimated with the annual number of affirmative U.S. decisions against a region as the dependent variable, coefficients are generally of the same signs as for total U.S. filings, with slightly better pseudo- $R^{2} s$ and overall fit of the equations. Once again, import penetration is not a statistically significant determinant of affirmative decisions, and the NAFTA dispute settlement filing variables have no statistically significant effects. ${ }^{15}$

\section{Econometric Analysis: Alternative Specifications}

Several alternative specifications were examined as sensitivity tests. Inclusion of year dummy variables or a trend term did not alter results. Several alternative measures of Chapter 19 activity by Mexico and Canada against the United States were also examined. One such measure is "successful" Chapter 19 cases, or cases remanded to the United States to reconsider the initial decision. In an empirical specification otherwise identical to the main specifications, these NAFTA dispute settlement remand measures have no significantly negative effect on U.S. antidumping and countervailing duty filings or affirmative decisions (table 4, rows 1 and 2). While not reported, the coefficient on import penetration continues to be statistically insignificant, suggesting that increased import

15. A number of alternative import measures were tried as control regressors, including real import growth, with no change in the explanatory power of import activity for U.S. antidumping and countervailing duty outcomes. One possible explanation for the poor performance of the import measures is the aggregate nature of the data. Movement in aggregate imports may mask substantial changes at the industry level. 


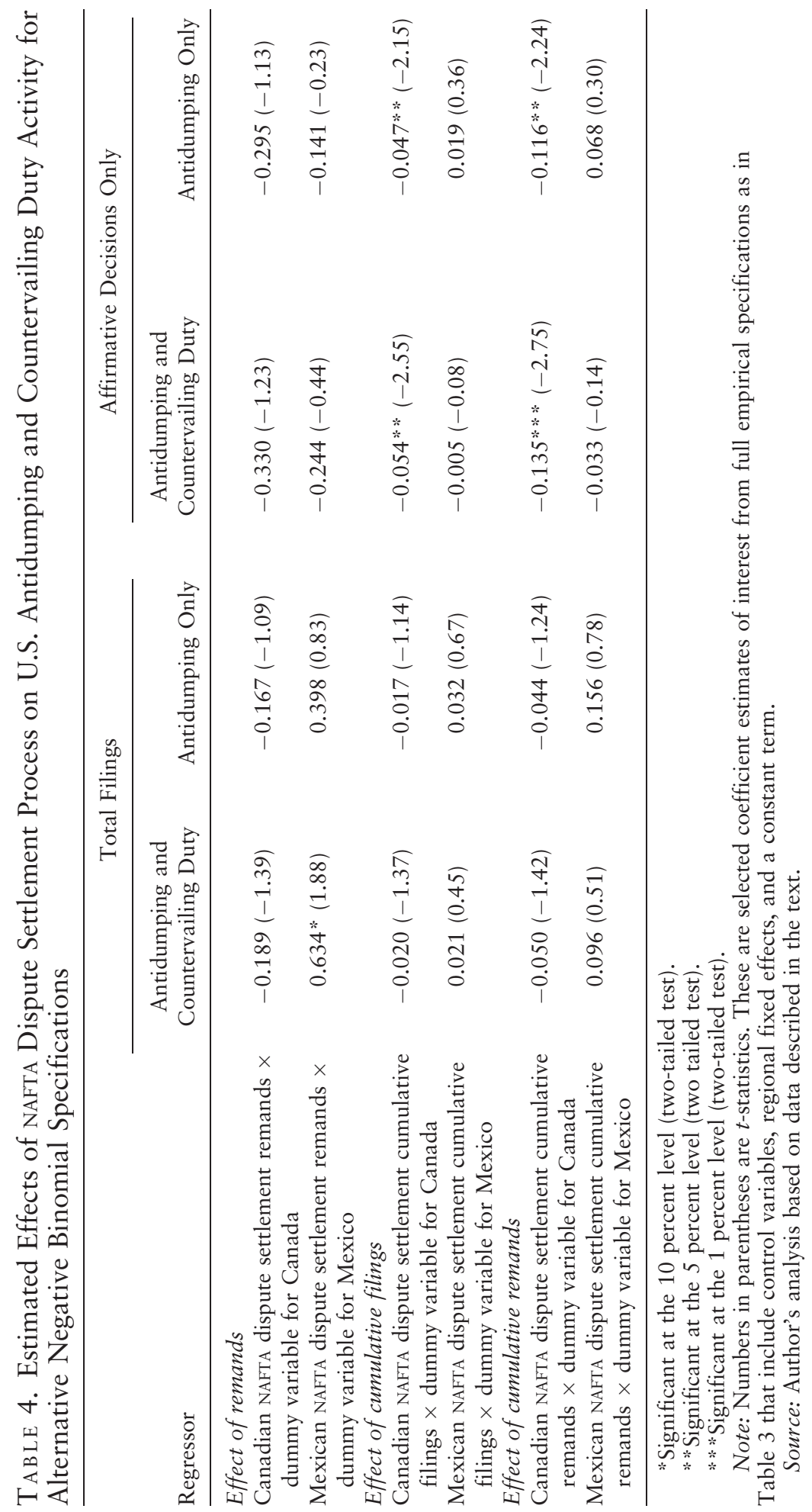


penetration from NAFTA, as in the main specification, does not affect U.S. antidumping and countervailing duty activity.

Another alternative measure of Chapter 19 activity is the cumulative number of dispute settlement cases to date, rather than just in the previous year. While there continues to be no effect on U.S. activity for Mexican filings and remands, cumulative Canadian filings and remands, although not affecting U.S. antidumping and countervailing duty filings, do significantly decrease the likelihood of affirmative decisions (table 4, rows 3-6). There are a number of possible explanations for this difference. One possibility may be that there has been a longer history of the dispute settlement process for Canada and the United States, and it takes time for various agents to understand the impact of the dispute settlement process on their incentives to file cases or rule affirmatively. A related explanation is that the history of the process to date has been one of quick decisions in Canadian dispute settlement petitions and long delays for Mexican petitions. Delays may make the process less effective in reducing U.S. antidumping and countervailing duty activity against Mexico.

A further sensitivity test is the examination of whether U.S. antidumping activity is affected by recent Canadian and Mexican antidumping activity. ${ }^{16}$ To examine this, the numbers of Mexican and Canadian filings and affirmative decisions against the United States were included as regressors in the specification with a one-year lag. ${ }^{17}$ As with most of the results with respect to Chapter 19 filings and determinations, Canadian and Mexican antidumping filings against the United States had no statistically significant effect on U.S. filings and affirmative decisions.

A final alternative specification examined U.S. antidumping and countervailing duty activity for steel cases only, which make up more than a third of all U.S. antidumping and countervailing duty cases for 1980-2000. This specification included explanatory variables specific to the steel industry, such as a steel industry growth variable rather than the real GDP growth variable. Results are qualitatively identical to those for the overall sample, including no evidence for any effect of Chapter 19 dispute settlement activity on U.S. antidumping and countervailing duty filings against Canada or Mexico.

16. Blonigen and Bown (2003) find evidence that the incidence of U.S. antidumping petitions and affirmative outcomes is generally lowered by the potential for retaliation threats, but they do not examine this specifically for NAFTA countries. Prusa and Skeath (2002) find evidence of tit-for-tat antidumping filing behavior in worldwide patterns.

17. The author thanks Tom Prusa for sharing data on these Mexican and Canadian antidumping and countervailing duty filings since 1980. Such activity for more recent years can be found on the wTO web site http://www.wto.org/english/tratop_e/adp_e/adp_e.htm. 


\section{Conclusion and Policy Discussion}

Using a panel database of U.S. antidumping and countervailing duty activity for 1980-2000, this article finds little evidence that either increased import volumes or NAFTA Chapter 19 dispute settlement activity affected the frequency of U.S. antidumping and countervailing duty cases or affirmative determinations against Canada and Mexico. An exception is evidence that cumulative remands by Chapter 19 dispute panels to review U.S. decisions against Canada have led to fewer new affirmative antidumping and countervailing duty decisions against Canada, though this does not hold when examining only steel products. These results contrast with the limited previous literature, which generally suggests that Chapter 19 dispute panels reduce antidumping and countervailing duty activity.

These results have implications for future trade negotiations in preferential trading areas and the WTO since the Chapter 19 dispute settlement process was likely intended to rein in use of antidumping and countervailing duty laws by the United States. In both the CUSFTA and NAFTA, the United States tried to thwart any attempt by partner countries to affect its application of antidumping and countervailing duty laws. The compromise solution of Chapter 19 binational dispute settlement procedures had the potential to affect antidumping and countervailing duty activity because it allowed for timely dispute settlements by panels representing both countries involved in the case. A critical constraint, however, was limiting the Chapter 19 panels to rule only on whether a country has appropriately applied its own laws and practices. In addition, the panels have no ability to enforce judgments. While government agencies from all three countries have largely complied with remands from the panel, this process did not resolve the largest trade dispute it faced, the softwood lumber case with Canada, which required resolution through direct government negotiations.

The ineffectiveness of the compromise Chapter 19 panels to slow down U.S. antidumping and countervailing duty activity against Mexico may be viewed as another way in which preferential trading areas involving industrial and developing countries may not be very effective in freeing trade. This interpretation is consistent with recent literature (for example, Anson and others 2005; Carrere and de Melo 2004) that shows that rules of origin restrictions placed on Mexico through NAFTA limited the amount of effective trade liberalization.

The ineffectiveness of the Chapter 19 panels also raises the question of what avenues current and future partner countries may have to persuade the United States to reform or eliminate its antidumping and countervailing duty laws. One option is more aggressive retaliatory activity against the United States. Both Canada and Mexico have substantial enough trade volumes to retaliate effectively. Of course, such strategies could lead to a trade war rather than to a "disarmament" agreement.

A second option is to try to harmonize competition policies and push for folding antidumping policies into a common competition policy. Were 
antidumping and countervailing duty practices subject to the same strong criterion for action as current competition policy (at least in the United States), successful antidumping and countervailing duty cases would likely disappear.

A final alternative may be to argue for U.S. use of safeguard actions rather than antidumping and countervailing duty laws. Safeguard protection allows governments to impose temporary protection for a domestic industry, provided that imports are a significant cause of injury to the domestic industry. The explicit condition that safeguard actions are temporary is a clear improvement over antidumping and countervailing duty cases-the United States is still assessing antidumping duties and countervailing duties from cases as far back as the 1970s. In addition, the injury test for safeguard actions requires a more stringent test to prove that imports are a significant cause of injury, not just a nontrivial one. In addition, safeguards do not require investigations of "unfair trade practices," which use costly resources to examine criteria that most economists regard with skepticism.

\section{REFERENCES}

Anson, José, Olivier Cadot, Antoni Estevadeordal, Jaime de Melo, Akiko Suwa-Eisenmann, and Bolorma Tumurchudur. 2005. "Rules of Origin in North-South Preferential Trading Arrangements with an Application to NAFTA.” Review of International Economics 13(3):501-17.

Baldwin, Robert E., and Jeffrey W. Steagall. 1994. "An Analysis of ITC Decisions in Antidumping, Countervailing Duty, and Safeguard Cases.” Weltwirtschaftliches Archiv 130(2):290-308.

Blonigen, Bruce A., and Chad P. Bown. 2003. "Antidumping and Retaliation Threats." Journal of International Economics 60(2):249-73.

Blonigen, Bruce A., and Robert C. Feenstra. 1997. "Protectionist Threats and Foreign Direct Investment." In Robert C. Feenstra, ed., The Effects of U.S. Trade Protection and Promotion Policies. Chicago: University of Chicago Press.

Blonigen, Bruce A., and Thomas J. Prusa. 2003. “Antidumping.” In E. Kwan Choi and James Harrigan, eds., Handbook of International Trade. Oxford, U.K. and Cambridge, MA: Blackwell Publishers.

Carrere, Celine, and Jaime de Melo. 2004. “Are Different Rules of Origin Equally Costly? Estimates from NAFTA.” CEPR Discussion Paper 4437. London: Centre for Economic Policy Research.

Council of Economic Advisers. 2002. Economic Report of the President. Washington, D.C.: U.S. Government Printing Office.

DeVault, James M. 1993. "Economics and the International Trade Commission." Southern Economic Journal 60(2):463-78.

Feinberg, Robert M. 1989. "Exchange Rates and Unfair Trade." Review of Economics and Statistics 71(4):704-7.

Feinberg, Robert M., and Barry T. Hirsch. 1989. "Industry Rent Seeking and the Filing of 'Unfair Trade' Complaints.” International Journal of Industrial Organization 7(3):325-40.

Finger, J. M., H. Keith Hall, and Douglas R. Nelson. 1982. "The Political Economy of Administered Protection." American Economic Review 72(3):452-66.

Gallaway, Michael P., Bruce A. Blonigen, and Joseph E. Flynn. 1999. "Welfare Costs of the U.S. Antidumping and Countervailing Duty Laws.” Journal of International Economics 49(3/4):211-44.

Gantz, David. 1998. "Resolution of Trade Disputes Under NAFTA's Chapter 19: The Lessons of Extending the Binational Panel Process to Mexico." Law and Policy in International Business 29(3):291-363. 
Giesze, Craig R. 1994. “Mexico’s New Antidumping and Countervailing Duty System: Policy and Legal Implications, As Well As Practical Business Risks and Realities, for United States Exporters to Mexico in the Era of the North American Free Trade Agreement." St. Mary's Law Journal 25:885-1040.

Hansen, Wendy L., and Thomas J. Prusa. 1997. "The Economics and Politics of Trade Policy: An Empirical Analysis of ITC Decision Making." Review of International Economics 5(2):230-45.

IMF (International Monetary Fund). Various years. Direction of Trade Statistics Yearbook. Washington, D.C.

Jones, Kent. 2000. "Does NAFTA Chapter 19 Make a Difference? Dispute Settlement and the Incentive Structure of U.S./Canada Unfair Trade Petitions.” Contemporary Economic Policy 18(2):145-58.

Knetter, Michael M., and Thomas J. Prusa. 2003. "Macroeconomic Factors and Antidumping Filings: Evidence from Four Countries.” Journal of International Economics 61(1):1-17.

Macrory, Patrick. 2002. "NAFTA Chapter 19: A Successful Experiment in International Trade Dispute Resolution.” C.D. Howe Institute Commentary 168.

Moore, Michael O. 1992. "Rules or Politics? An Empirical Analysis of ITC Anti-Dumping Decisions." Economic Inquiry 30(3):449-66.

NBER (National Bureau of Economic Research). Various years. "U.S. Antidumping Database." Cambridge, MA (http://www.nber.org/antidump).

Pippin, Kenneth J. 1999. "An Examination of the Developments in Chapter 19 Antidumping Decisions Under the North American Free Trade Agreement (NAFTA): The Implications and Suggestions for Reform for the Next Century Based on the Experience of NAFTA after the First Five Years." Michigan Journal of International Law 21(1):101-30.

Prusa, Thomas J. 2001. "On the Spread and Impact of Anti-Dumping." Canadian Journal of Economics 34(3):591-611.

Prusa, Thomas J., and Susan Skeath. 2002. "The Economic and Strategic Motives for Antidumping Filings.” Weltwirtschaftliches Archiv 138(3):389-413.

USDA ERS (U.S. Department of Agriculture, Economic Research Service). Various years. Exchange Rate Data Set. Washington, D.C. (http://www.ers.usda.gov/data/sdp).

U.S. GAO (General Accounting Office). 1997. "North American Free Trade Agreement: Impacts and Implementation." Testimony before the Subcommittee on Trade, Committee on Ways and Means, House of Representatives. Washington, D.C.: U.S. Government Printing Office.

Vega-Canovas, Gustavo. 1997. "Disciplining Anti-Dumping in North America: Is NAFTA Chapter Nineteen Serving Its Purpose?” Arizona Journal of International and Comparative Law 14(2):479-501. 